Alex GOLDIȘ

Faculty of Letters, Babeș-Bolyai University, Romania

Cluj-Napoca, Romania

alexandru.goldis@ubbcluj.ro

\title{
THE UNTRANSLATABLES OF WORLD THEORY. A GEOPOLITICAL OUTLOOK
}

Recommended Citation: Goldiș, Alex. "The Untranslatables of World Theory. A Geopolitical Outlook”. Metacritic Journal for Comparative Studies and Theory 7.2 (2021). Doi: https://doi.org/10.24193/mjcst.2021.12.07

\begin{abstract}
The paper investigates the cultural transfers and translations of the term "theory", as instrumented in some of the most influential anthologies of the past decades. It puts forward the argument that while in literature per se a widening of the canon has been produced, "theory" remains a term charged with high hegemonical presumptions. Therefore, it pleads for a non-hierarchical and practical conception of theory, that can account for the large variety of non-Western literary phenomena.
\end{abstract}

Keywords: theory, theory anthologies, world literary knowledges, semi-peripheral cultures.

In the last decades, one of the main tasks of disciplines or approaches like comparative literature, postcolonialism or the more recent world literature studies has been to enlarge the canon and to absorb cultures left aside by a hierarchical Republic of Letters. Moreover, quantitative analysis or distant reading created the premise of examining large amounts of texts. The dictatorship of the 1 percent of consecrated works over the 99 percent remaining in the shadow of the canon is considered obsolete. Moreover, literary studies that investigate phenomena extending over large periods of time or wide geographies by means of extrapolation are becoming illegitimate. Statistics, data mining or general computing technologies are frequently put to use in favour of this ever- 
widening territory of literary material. The most recent approaches allow analysts to encompass entire literatures over several continents.

However, one can easily notice that a similar re-territorialization did not occur in the field of theory as such. While anthologies of world literature in recent years reflect a constant broadening of horizons, the field of epistemology has remained rather conservatory. For instance, the Norton Anthology of Theory and Literary Criticism by Vincent B. Leitch - the third edition was issued in 2018 - does not include non-Western contributions. The collection mingles both ancient and modern reflection on literature, with a considerable number of contributions from philosophers like Plato, Thomas Aquinas, Hegel or Foucault, linguists like Saussure, writers like Dante, Wordsworth, Baudelaire or literary critics/theorists like Kenneth Burke, Georges Poulet, J. L. Austen or Franco Moretti. It is worth observing that even when the definitions of theory and literary criticism are not narrowly circumscribed - on the contrary, the Norton anthology seems to equate the terms on the cover of the book with any reflection on literature -, non-Western authors are totally excluded from the map. By non-Western I mean not only contributions from continents other than Europe or America, but also contributions from Eastern Europe. The Prague School or the Russian formalist school are misrepresented - with small texts from Eikhenbaum, Bakhtin or Jakobson only. Other examples of such anthologies do not show spectacular signs of progress: the 2014 Routledge Anthology of Global Literary Theory, although aiming at higher geo-cultural coverage, remains confined within Eurocentric frontiers. The texts that engage nonWestern concepts remain chiefly tributary to the „Europe - and” paradigm of analysis (Chow 2004: 294): for instance, Pal Ahluwalia investigates the Algerian roots of Derrida's theory of deconstruction, Asian culture is represented by a parallel between Levinas and Lao-zi. A couple of other contributions, however salutary, about the internet in China or the pirate electronic cultures in India, fail from making the book a guide to reading globally, as the authors intended.

More such examples can certainly be invoked. Thus, perhaps it is not far-fetched to state that the turn toward the global is not equivalent with an increased interest in world poetics or world literary theory. If the geopolitics of literature has been constantly challenged in the last decades, a reflection on the hierarchical field of literary 
knowledges is still under way. One of the first authors to react against the idea that there are cultures that produce metacritical discourse while others remain genuinly artistic is Revathi Krishnaswamy. In a 2010 text, she questions the „widespread assumption that theory is the product of a uniquely Western philosophical tradition” and that „the nonWest may be a source of exotic cultural production, but cannot be a site of theory" (135). The uneven distribution of power, as established by Immanuel Wallerstein decades ago in the field of economics, can also be applied to the world literary system: while there are cultures presumed to produce the technological framework for understanding and analyzing literature (the theoretical flags on the map), others are thought to provide only the raw material for abstract notions. It is worth noting that the revision of the world canon in postcolonial context only implied two general mechanisms: on the one hand, the widening of the literary material with literatures or works considered peripheric; as far as epistemology is concerned, on the other hand, the enlargement of the canon was often equated with studying the dissemination in so-called subaltern literatures of theories and concepts elaborated in core cultures. Questions like is there a Romanian or a Hungarian post-structuralism, can one speak of postmodernist undercurrents in South African culture or is there a paraguayan postmodernism, all employ this core-to-periphery oriented discourse. The dynamic of power at the level of world-scale literary institutions tends to create, more than a set of individual analogies, rather a network of structural homologies (Goldiş 2018) that govern the relations between cultures: the tendency to revise the canon by merely replicating theories, concepts and disciplines in subaltern contexts - rather than undermining its authority, ends up reinforcing it. The extension of the theoretical canon has been often equated with the tendency to demonstrate that feminist studies, structuralism or psychoanalysis not only possess headquarters on the Western territory, but rely on important subsidiaries in so-called marginal cultures as well.

At issue here are the status and the map of theory, as drawn by its most important defenders. In an interview with Vincent B. Leitch, the editor of the Norton anthologies series, a Chinese scholar, professor Zhu Gang at the Nanjing University, hints at the privileged status of theory in the broader economy of literary values: to him, the term often designates „a decoration of the ivory tower”, „a proof of sophistication, a 
pre-requisite of the MA thesis and Ph. D Dissertation" (Gang 2009: 5). Although the statement might be dismissed as exaggerated, the questions „why did literary theory become such a high valued commodity in the Western world and how did the Western theoretical tradition emerge as the privileged marker of cultural superiority" (R. Khrishnaswamy) are worth asking. A real battle for the appropriation of the term is perhaps most visible in the constant re-drawing of its map. In a line of thought stemming from the introductory studies of Jonathan Culler or Terry Eagleton, the aforementioned Routledge Global Literary Theory anthology locates its birth in the Europe of the 1960 s (formalism is registered as a predecessor), while also insisting on its expansion in the cultural field of the United States. On closer inspection, one can easily notice that the definition of theory is plainly situated under post-structuralist premises. „Suspicion”, „reaction against authority”, uncovering problematic systems of thought and behavior, identifying the logical flaws and contradictions of texts - are clearly located features of theory. For Culler, theory is not about the study of literary texts, but a mode of transgressing disciplinary boundaries. Theory has come to designate works that succeed in challenging and reorienting thinking in fields other than those to which they apparently belong" (Culler 1997: 3). An even stronger metaphor for theory, although its significance is similar, is that of Suman Gupta's "Globalization and Literary Studies" study, that of 'hijacking': theory reflects the hijack of culture by literary studies" and viceversa. Richard Lane's anthology reflects, indeed, this ideology of crossing boundaries, as the book includes works of art history, anthropology, media studies, gender studies, psychoanalysis, economic and social approaches.

In order to de-construct this hegemonic meaning of theory, Galin Tihanov located its origins in Eastern Europe, while assigning it a definition in line with what he calls a modernist or aesthetic regime of relevance. Theory emerges in Eastern Europe at the beginning of the $20^{\text {th }}$ century, Tihanov states clearly, as a competitor that wins over other disciplines as aesthetics or philosophy. The formalist and the Prague school movements, only mentioned as predecessors in the above referenced anthologies, are strong arguments for locating the origins of theory on the Eastern map, at the crossroads between several cultures. As opposed to the Western definition of theory, built around the transgressing of borders between disciplines or the deconstruction of 
received ideas, Tihanov insists on its commitment to the autonomy of the aesthetic, merged with the positivistic intend to build up a literary system. For the comparatist, theory is literary theory. Shklovsky, Bakhtin, Jakobson are not merely predecessors of the $20^{\text {th }}$ century meta-critical discourse, but founders whose work have anticipated the major issues later addressed by French Theory.

These geographical shifts - if not conflicting visions - only reinforce the idea that there are no generally accepted definitions of theory. Perhaps the safest statement that can be made, other than that of admitting that we deal with „a body of thinking and writing whose limits are exceedingly hard to define" (Culler 1997: 3) is that 'theory' has been/is still a site of negotiating relations of symbolic power on worldwide scale. This is why, in the above mentioned text, Revathi Krishnaswamy calls for a more democratic understanding of the term. In fact, she questions the term itself as ideological and replaces it with the more relativistic syntagm of „world literary knowledges” to include, in fact, not only the "formal explicit systematic discourses of dominant, prestigious, textual traditions", but also "regional, subaltern and popular epistemologies that may be emergent or embryonic" (Krishnaswamy 2010: 408).

And indeed, so-called peripheric or semi-peripheric cultures - if we admit the conventional taxonomy put to use by recent World Literature scholars - provide an important number of issues and topics with high potential of becoming epistemologies of their own. Among the most obvious topics of contention coming from non-western cultures are the status of second languages, religions, minority literatures, strategies of translation. A book like that of Pascale Casanova, The World Republic of Letters, although preserving Western-Parisian biases, has called attention to the serious and very complex reflection on the subaltern condition employed by the works of writers residing in the peripheral geography of Literature. Rather than theoretically-challenged environments, as one could euphemistically name them, Eastern Europe, South America and other zones are privileged sites of reflection on what the anxiety of not being central means (the Romanian critic Virgil Nemoianu even puts forward a theory of the secondary), on the strategies employed in order to reduce this assymetry, on the importance of cultural heritage or translation and so on. The entire history of Romanian meta-critical thought - and I am sure this is a common experience - can be re-written 
with regard to strategies and projects (in fact, theories on their own) of international recognition. In a follow-up essay to her World Republic of Letters, Casanova overtly states the privilege of so-called combative/marginal literatures over pacifist or central cultures in terms of reflection on the negotiation between literature and other values. If pacifist cultures with established traditions are rather blind to the process of the accumulation of cultural capital, the combative ones are dynamic platforms of reflection on how literature can be preserved and protected under harsh social or political contexts (Casanova 2011). A similar point has been recently made by Marko Juvan in a book investigating the prerequisites of peripheral cultures for becoming central. The Slovenian scholar points out that the very concept of world literature, as coined by Goethe at the beginning of the XIXth century, „grew from his uncertainty about the position of German literature vis-à-vis traditionally established national literatures of Western Europe" (Juvan 2019: 8). The syntagm which has benefited from a spectacular revival in the literary studies of the recent decade is a living proof that one can theorize from the margins of the system.

But perhaps theory - or world literary knowledges, as Khrishanswamy renames it - is not only emergent or informal reflection on literature. Theory is always embedded in concepts like genre, form, system of representation or wider equations like the regime of literature in specific parts of the globe or at certain points in time. Surprisingly, even critical accounts that try to dismantle the Western canon tend to overlook that these variables need theorizing between being put to actual use in comparative approaches. One such example comes from Franco Moretti's influential Conjectures on World Literature. Following a hypothesis put forward by Fredric Jameson, Moretti employs his distant reading method in order to conclude that in marginal cultures modern novel is born "as a compromise between foreign form and local materials - more precisely, foreign plot; local characters; and then, local narrative voice" (Moretti 2000: 65). However, specialists in Indian novel are reluctant to such simplifying cultural equations. In a 2006 study hosted in a collective volume edited by Moretti himself, Meenakshi Mukherjee points out that "the boundary between what was absorbed from local practice by a process of osmosis and what was learned from Western models consciously is not such an easy line to draw" (Mukherjee 2006: 599). Moreover, the concepts by 
which critics address issues of the Indian novel are all too often tools of domestication: what is called in Western critical discourse a device of authorial intervention (or the Dear reader convention of the Victorian fiction) is not merely a technique in the XIXth century Indian novels, but a constitutive link in building community values in the tradition of ritual storytelling of khatakhata. Categories like 'realism' or 'epic' are equally questionable when applied to Indian literary realities: „Epic in the context of India means neither 'primary epics' like the Iliad or the Odyssey, nor the secondary variety written by Virgil or Milton. In fact, there is no exact synonym for epic in Sanskrit-the language in which the Ramayana and the Mahabharata were originally composed. In English, both are referred to as epic, but the category for the Ramayana in Sanskrit is kavya (narrative in verse) or mahakavya (long narrative in verse); for the Mahabharata, it is itihasa ('thus it happened'-what is now called history) or itihasapurana, which is one of the many subdivisions of the generic term purana (meaning stories of the gods)" (Mukherjee 2006: 601). Perhaps a dictionary of theory untranslatables, similar to the one dedicated to philosophical terms by Barbara Cassin, would uncover the premises underlying the literary categories of so-called un-reflexive cultures.

To sum up, I cannot overstate the idea that there are no implicit rules of literary epistemology when we move from a continent to the other or even when we shift our interest from one culture to another. Perhaps the demise or even the death of the theory, as proclaimed incessantly in the last decades - or just its newfound role of „regular practice as opposed to shocking and disruptive vanguard" (Leitch 2014: 2) - are not such bad news at all. Neither is the effacement of the term altogether, which may signal the dissolution of the ideologies attached to it. Instead of an elitist set of metadiscourses, with high colonial potential and with a strict disciplinary taxonomy, it may prove more useful to imagine theory as a "conceptual lab" (the term belongs to Christian Moraru), or „a helpful, but indispensable, toolkit for long-established fields and areas of literary and cultural study" (Leitch 2014: 3). 
Acknowledgement: This work was supported by a grant of the Romanian Ministry of Education and Research, CNCS-UEFISCDI, project number PN-III-P1-1.1-TE2019-o946, within PNCDI III.

\section{References:}

Casanova, Pascale. "Combative Literatures". New Left Review. 72 (2011), pp. 123-134.

---. The World Republic of Letters. Trans. by M. B. DeBevoise. Harvard University Press. 2004.

Cassin, Barbara. Apter, Emily. Lezra, Jacques. Wood, Michael. Dictionary of Untranslatables: A Philosophical Lexicon. Princeton University Press, 2014.

Chow, Rey. "The Old/New Question of Comparison in Literary Studies. A PostEuropean Perspective”. ELH 71.2 (2004), pp. 289-311.

Culler, Jonathan. Literary Theory. A Very Short Introduction. Oxford University Press, 1997.

Gang, Zhu. "Theory Today and Tomorrow: An Interview with Vincent Leitch". Foreign Literature Studies 31(5) (2009), pp. 1-9.

Goldiș, Alex. "Beyond Nation Building: Literary History as Transnational Geolocation", in Mircea Martin, Christian Moraru, Andrei Terian (eds.), Romanian Literature as World Literature. Bloomsbury Publishing, 2018, pp. 95-115.

Gupta, Suman. Globalization and Literature. Polity Press, 2009.

Eagleton, Terry. Literary Theory. $2^{\text {nd }}$ Edition. Blackwell Publishing, 1996.

Juvan, Marko. Worlding a Peripheral Literature. Palgrave Macmillan, 2019.

Krishnaswamy, Revathi. "Toward World Literary Knowledges: Theory in the Age of Globalization”. Comparative Literature 62.4 (2010), pp. 399-419.

Lane, Richard J. Global Literary Theory. An Anthology. Routledge, 2014.

Leitch, Vincent B., Cain, William E., Finke Laurie A. The Norton Anthology of Theory and Criticism. $3^{\text {rd }}$ Edition. WW Norton \& Co, 2018.

Leitch, Vincent B., Literary Criticism in the $21^{\text {st }}$ Century. Theory Renaissance. Bloomsbury Academic, 2014.

Matei, Alexandru, Moraru, Christian, Terian, Andrei. 'Introduction: Toward a 'Post' Vocabulary - A Lab Report”, in Matei, Alexandru, Moraru, Christian, Terian, 
Andrei (eds.), Theory in the "Post" Era. A Vocabulary for the 21 $1^{\text {st_Century }}$ Conceptual Commons. Bloomsbury Academic, 2022, pp. 1-35.

Moretti, Franco. "Conjectures on World Literature". New Left Review 1 (2000), pp. 5468.

Mukherjee, Meenakshi, "Epic and Novel in India". Franco Moretti (ed.), The Novel. Princeton University Press, 2006, pp. 597-631.

Nemoianu, Virgil. The Theory of the Secondary:Literature, Progress and Reaction. Johns Hopkins, 1989.

Tihanov, Galin. The Birth and Death of Literary Theory. Regimes of Relevance in Russia and Beyond. Stanford University Press, 2019.

Wallerstein, Immanuel. World-Systems Analysis. An Introduction. Duke University Press, 2004. 